\title{
Programming Where the Kids Are: An Informal STEM Series at Day Camps to Improve Attitudes Toward Science and Engineering
}

\author{
Mitch Mason ${ }^{1}$, Kristy L. Ouellette ${ }^{1}$, and Sarah Sparks ${ }^{1}$
}

\author{
${ }^{1}$ University of Maine Cooperative Extension 4-H \\ Keywords: 4-H, informal, youth development, engineering, day camp, aspirations \\ Publication Date: December 7, 2018 \\ DOI: https://doi.org/10.15695/jstem/v1i1.26
}

\begin{abstract}
H is the youth development program of the Cooperative Extension and has identified Science, Technology, Engineering, and Math (STEM) as a national priority. Conducting STEM education during summer months for hard to reach youth can be a challenge. However, it is during summer when vulnerable students most often experience learning loss. During the summers of 2016-17, 4-H in Maine taught STEM lessons at local day camps ran by an experienced, nationally recognized youth development organization. An average of 214 youth in grades 3-6 participated weekly over the two summers. Lessons were created or assembled by University of Maine staff, delivered by college interns, and evaluated by faculty. Day campers were surveyed about their experience and feedback data were obtained from program partners and college interns to create formative and summary results. This paper describes the successes and challenges of the two year process to deliver quality STEM programs where the kids are.
\end{abstract}

\section{INTRODUCTION}

Since the Cooperative Extension service was established in 1914, its mission has been to be where the people are; to be embedded in local neighborhoods and communities where Extension agents can conduct education, research and outreach to meet local needs (U.S. Department of Agriculture, 2018, paragraph 1). Cooperative Extension has almost 3,000 county-based offices located across the U.S. and every office has a formal tie to a state land-grant university. To best fulfill its mission, Cooperative Extension has a directive to bring campus-based research to local communities in practical and relevant ways, often through 4-H. 4-H is the youth development program of the Cooperative Extension and in Maine has as its mission "to educate and empower Maine youth through hands-on and community-based experiences". 4-H exists in conjunction with land-grant universities in all U.S. states and territories, and has identified Science, Technology, Engineering, and Math (STEM) education to be a priority outreach program for American children ages 5-18 (National 4-H Council, 2012).

In Maine many students do not get much classroom science instruction before middle school. A 2016 (unpublished) survey conducted by the Maine Science Teachers Association reports that $90.2 \%$ of schools grade $\mathrm{K}-2$, and $65.5 \%$ grades 3-5, provide science instruction 60 minutes or less per week. There is also evidence that teachers will allocate fewer hours to science when state accountability reports do not collect data on science learning outcomes (Judson, 2013); elementary students in Maine rarely have standardized testing about science. Research indicates that schools focus on instructional time for reading and math due to those subjects being tested more often than science (Shanahan et al., 2011).

In many Maine communities the consequences of de-emphasizing K-5th grade science is evident in the Maine Educational Assessment (MEA) standardized test. In 2016-17, barely half of students scored at grade level or better in science (Maine Department of Education, 2017). Math scores were even lower with only $38.5 \%$ of Maine students scoring at or above state expectations. It is important for Maine's future that young adults are proficient in the STEM fields. Business leaders in Maine report unmet demand for STEM trained employees and unemployment in STEM occupations is lower than other careers (U.S. Census Bureau, 2017).

Research shows that children develop attitudes and opinions about science early. By middle school those attitudes are difficult to change (Gibson and Chase, 2002), and it is difficult for students without exposure to science prior to middle school to catch-up with their more scientifically literate peers later on (Nelson and Landell, 2007). It is important to find avenues to nurture science literacy and aspirations in 
grade school youth wherever possible.

For English Language Learners, a growing population in southern Maine, more than $80 \%$ of students are not meeting Maine learning expectations (Maine Science Teachers Association, 2017). The issue is made worse by documented understanding that low-income students have less than average access to science education. The achievement gap is perpetuated during summer months for low-income students, who lose more grade equivalency due to lack of out-of-school and summer learning opportunities. A 2015 analysis of spring and fall test scores for Maine students in grades 3-8 found that summer learning loss was greater in math than reading and students from economically disadvantaged backgrounds were more adversely affected by summer learning loss than Maine students from higher resource families (Silvernail and Mazjanis, 2015).

The engagement of girls in STEM work and study is an ongoing topic of concern. The gender disparity in pay, employment opportunities, educational attainment and recognition is well documented. Some research suggests that science may be attractive as a subject but that related industries don't motivate many women to pursue science work (Diekman et al., 2017, Stake, 2006, Moss-Racusin et al., 2018). A study by the National Academy of Engineering (2008) examined engineering marketing tag lines that could be used to attract more youth to the engineering field. Their research found that tag lines emphasizing making a difference and helping others were most attractive to girls and that there was a difference in boys' and girls' responses to engineer descriptions.

Inquiry-based learning in particular has been shown to be an effective model for educational achievement in sciences (Arnold, 2013) as well as the application of science principles during out-of-school time (Braund and Reiss, 2007; Dillivan and Dillivan, 2014). Inquiry-based learning is described by Ripberger (2011) as, "an approach to learning that utilizes discovery and scientific thinking processes to explore and learn knowledge and skills". The Next Generation Science Standards Framework (National Research Council, 2012) emphasizes the need for students to engage in scientific inquiry and engineering design practices. Inquiry based learning, as described through the Next Generation Science Standards, has been shown to increase engagement of English Language Learners (Archer et al., 2010) in science and engineering while also assisting with language acquisition and application (Miller et al., 2014).

All six lessons delivered and evaluated as part of this research were inquiry-based in design and integrated the Engineer Design Process. The Engineer Design Process, while distinct from inquiry based learning, has several equivalent practices and components (National Research Council, 2009).

Content Rich Partners. Cooperative Extension has learned that developing strategic partnerships is critical to meeting its mission. Extension has far-reaching experience in partnering with community-based organizations to affect change. Extension staff regularly partner with private industry (Romich and Campbell, 2015), schools (Seevers and Stair, 2015), and non-profits (Bassano and McConnon, 2011). For 4-H staff, developing community partnerships is an expected competency (United States Department of Agriculture, 2017). Increasingly, Extension has reached out on its own campus to access expertise outside of its core content areas of agriculture, nutrition, youth development, and community development (Scutchfield et al., 2007).

The Established Program to Stimulate Competitive Research (EPSCoR) is another campus-based entity with a mission similar to Cooperative Extension. EPSCoR seeks to develop, "partnerships between their higher education institutions, industry, government, and others to effect lasting improvements in their R\&D infrastructure, capacity, and national competitiveness" (National Science Foundation, 2018). A major initiative of UMaine EPSCoR is to build a research network in Maine called Sustainable Ecological Aquaculture Network (SEANET). SEANET seeks to foster the next generation of engineers, researchers and entrepreneurs that will grow Maine industry, innovation and social capital. To fulfill its mission, EPSCoR has supported infrastructure building projects, major equipment purchases, and new faculty hires. EPSCoR has also supported a broad spectrum of engineer education and aquaculture research including the UMaine 4-H Summer of Science program.

\section{Meeting the Need for Summer Inquiry-Based Learning.} UMaine 4-H has coordinated a 4-H Summer of Science program since 2011 and in partnership with EPSCoR since 2016. The program model identifies a minimum of six science lessons to be delivered at community-based sites. The program brings inquiry-based learning directly to the target audience. The minimum of six lessons was adopted from the 4-H SPIN (special interest club) model. Six lessons was also optimal for the timeframe in which available youth would be attending informal summer learning programs. The program started in 2011 as a method of reaching youth who were not likely to attend an organized campus-based educational program but who did attend Summer Food Service Programs (SFSP), a free lunch program (an audience most likely to experience summer learning loss and not have access to summer enrichment programs). In subsequent years, the 4-H Summer of Science has expanded to 30 sites in nine communities across three Maine counties and partners with summer schools, youth organizations, summer food sites, libraries, and housing authority sites. This study discusses the results of programming in 2016 and 2017 at summer day camp sites led by a national recognized youth development organization partnering with $4-\mathrm{H}$. These sites were select- 
ed for analysis because of consistency in attendance at the camps, uniformity between the camp sites, and applicability of the camp delivery model. In order to reduce barriers for participation and reach the intended underserved audience, the activities are provided at low or no cost to the community partner and participants.

4-H Summer of Science activities are chosen around a theme with priority given to lessons that have local relevance to both research and workforce development. Materials need to be able to be gathered in bulk, be low cost for consumable items, and be limited in use of electricity and/ or water, which may not be readily available at sites. Activities also need to be developmentally appropriate for the audience intended to be reached. In this program model the target is grades 3-6. The activities need to be based in good science but clear enough that anyone with basic training in teaching methods can pick up the lesson and understand the learning objectives and content. The 4-H sustainability model relies on staff or paraprofessionals as place-based educators. Once activities are identified for the year materials are gathered and organized by region so they can be easily distributed based on sites. Quality training of informal, community-based teachers can lead to increased ease in leading inquiry-based learning and more effective usage of proper tools and techniques (Haugen et al., 2016).

Program Delivery. The 4-H Summer of Science is coordinated by 4-H staff, but usually delivered by volunteers, student interns and high school teen teachers (summer program staff) throughout southern Maine. Although there are no teen teachers at the day camps in this study, the lessons are designed for teens to use as teen teachers, always with an adult partner for supervision and support. UMaine 4-H provides 40 hours of initial training with summer program staff, instructing on positive youth development, experiential learning, and specific training around the identified summer theme and lessons. Summer program staff are matched with a community site where youth already gather during the summer. Summer program staff facilitates at least one activity, per site, per week during the summer sessions. This study summarizes, 1) the processes to implement a remote, mobile STEM curriculum, 2) taught by college interns, 3) the perceived effectiveness of remotely teaching STEM, and 3) measured attitudes toward science and engineering of youth who participated.

\section{METHODS}

The STEM Lessons. There were eight weeks of lesson delivered in 2016 and six weeks of lesson in 2017 to day campers at seven camps in southern and eastern Maine. Each weekly lesson was about one hour in length; all youth received the same lessons in the same week. Lessons were taught at multiple sessions at each day camp site in order to keep class sizes manageable. The lessons were focused on aquaculture (2016) and engineering (2017). Considerations for choosing lesson content included:

- Relevancy to living and working in Maine.

- Current research at the University of Maine (specifically research supported through EPSCoR and Cooperative Extension).

- Existing resources and expertise of University of Maine faculty and staff.

- Interest of organizations hosting the lessons.

- Goal to create a problem and inquiry-based learning experience for students.

The decision was made to create lessons derived from EPSCoR's Sustainable Ecological Aquaculture Network (SEANET) initiative; specifically lessons from research on Maine seaweed (2016) and marine related engineering (2017). A funding priority for SEANET is "creating STEM and workforce development opportunities across the K-20 pipeline." Environmental science, particularly marine science, is an important matter for Maine families and its economy (Wallace et al., 2017; Safford and Hamilton, 2012).

In 2016, a full-time graduate student with EPSCoR produced an original, eight lesson curriculum called 4-H Aquaculture: Seaweed and then piloted the curriculum in the Spring of 2016 in partnership with 4-H staff. In 2017 the decision was made to modify independent activities into a six lesson curriculum. Those six lessons were adapted from 4- $H$ Aerospace Adventures and How to Smile (a clearinghouse of out-of-school-time science activities supported by multiple national partners including $4-\mathrm{H})$. The title and theme of the lessons can be found in Table 1 .

All lessons utilized the constructivist approach to learning through implementation of the 5E Instructional Model (Engage, Explore, Explain, Elaborate, Evaluate). Each week the STEM lesson started with an engaging opening activity, then an exploration of the lesson through experimentation, an explanation by participants of what happened in their experiment, an elaboration by the instructor and finally a group evaluation of the activity to end the lesson. Steps and structures of each lesson were designed to be as consistent as possible from week to week to create predictability for students who were learning in an informal setting. The predictable lesson structure was also intended to aid inexperienced interns and camp staff in attendance to be more efficient and effective in teaching.

An important design piece of the lessons was the inclusion of problem-based learning (PBL) opportunities. Utilization of problem-based learning has been shown to increase aspirations towards a STEM career (LaForce et al, 2017; Lou et al., 2010). Participants were challenged to explore solutions to a problem (i.e. design a seaweed farm, co-create a car 
Table 1. 4-H Summer of Science lessons in 2016 and 2017 by title and content.

\begin{tabular}{|c|c|c|}
\hline Schedule & 2016: Aquaculture Lesson & 2017: Engineering Lesson \\
\hline \multirow{2}{*}{ Week 1} & Maine Seaweed Identification. & Sugar Spill! \\
\hline & Recognizing local seaweed characteristics & Bioremediation \\
\hline \multirow[b]{2}{*}{ Week 2} & Go Fish for Seaweed. & Watersheds. \\
\hline & Identify parts of seaweed & Point pollution \\
\hline \multirow[b]{2}{*}{ Week 3} & Photosynthesis Model. & Animal Adaptations. \\
\hline & Develop a model and understand photosynthesis & Biomimicry \\
\hline \multirow{2}{*}{ Week 4} & Nutrient Cycle Game. & Chromatography. \\
\hline & Create stations that mimic nitrogen movement & Matter, molecules, and mass \\
\hline \multirow[b]{2}{*}{ Week 5} & Gulf of Maine Jenga. & Pressure! \\
\hline & $\begin{array}{l}\text { Use modified Jenga game to model layers of ocean } \\
\text { ecosystem }\end{array}$ & Air pressure and pollution \\
\hline \multirow[b]{2}{*}{ Week 6} & Seaweed Farm Challenge. & Language of Engineering Design. \\
\hline & Use defined materials to build a seaweed farm model. & Drawing a design to make a simple car \\
\hline \multirow[b]{2}{*}{ Week 7} & Got Seaweed? & \\
\hline & $\begin{array}{l}\text { Learn about sodium alginate and seaweed as consumable } \\
\text { product }\end{array}$ & Evaluation \\
\hline Week 8 & $\begin{array}{l}\text { Rockweed Harvesting Game. } \\
\text { Explore sustainability using a model of Maine's rocky } \\
\text { shore. }\end{array}$ & None \\
\hline
\end{tabular}

with limited materials, find a way to measure the advantage of feathers on a ptarmigan's feet), usually in small groups to facilitate communication skills. Students were tasked with using available materials to either replicate an engineering design solution or to design a solution to an engineering problem. Interns and camp staff were provided with lessons on using inquiry as a teaching tool and were encouraged through the lesson plans to use that tool

Since the interns were not experienced educators, their lesson plans included basic information to facilitate their success including key vocabulary words to emphasize, questions of inquiry to use along with prompts as to when to use them, and supplies and materials in order of use.

The Instructors. Three paid college interns were hired and trained to deliver the STEM lessons. Interns were recruited at local colleges and were interviewed and hired as full-time, temporary university staff and received a stipend and mileage. All three college student interns from 2016 returned to teach in 2017, suggesting a rewarding learning experience for the interns. The college interns received one week of training from 4-H staff on Positive Youth Development, Risk Management, Teaching Methodology, and the STEM lesson plans. The interns were required to physically visit each teaching site the week prior to teaching lesson 1 to observe the facility, meet the day camp staff and to ask questions. During the summer program, interns met every Monday morning with 4-H staff to review previous weeks' results, provide programmatic feedback, and to prepare for upcoming lesson. Lessons at an additional site in eastern Maine in 2017 were taught by an experienced local staff member; following an initial orientation, the 4-H staff member in eastern Maine checked in with other project staff periodically.

The Student Learners. The youth who participated in the 2016 4-H Summer of Science lessons were registered at one of five day camps (six in 2017) in southern or eastern Maine. The 4-H Summer of Science program was designed for all students attending the camps in the target age range. Students did not enroll in the 4-H Summer of Science STEM program specifically, but families were made aware during camp registration that the program would take place and their child would participate unless the family or child opted out of 4-H Summer of Science. There were no children or families who opted out.

There was an average of 221 campers at each lesson in 
2016 and 206 campers in 2017. There were fewer on average in weeks 3,4 , and 5 of the middle of the program due to students attending summer school. Daily attendance at the program was not taken although a majority of students were enrolled in their respective camp throughout summer. Any student who did not attend more than one session was not included in survey results. The survey did not delineate for number of sessions attended; self-report of attendance by students was not deemed to be accurate.

Parents were notified of the weekly 4-H STEM program and the survey through a newsletter and through texts. The survey was taken by youth participants in 2017 anonymously. The survey was administered in paper form by $4-\mathrm{H}$ staff at the end of the six week program. 4-H staff explained the purpose of the survey to the students. Participation was not compulsory but students were not verbally told they could opt out. All surveys were reviewed and approved by the Institutional Review Board of University of Maine.

The Partnerships. Purposeful partnerships were created between the funding agency (EPSCoR), the program design team (Cooperative Extension), and the day camps which enrolled the children. EPSCoR and 4-H staff gathered monthly starting six months prior to the programming to discuss objectives, outcomes, budgeting, hiring, and evaluation. 4- $\mathrm{H}$ staff started communications with camp host site leaders four months prior to programming. A 4-H staff person presented the curriculum to newly hired camp staff two weeks prior to programming and each camp sent home information to parents about their child's participation in the STEM activities. All interns and 4-H staff visited all camp sites prior to programming. There was weekly communications between 4-H staff and camp sites during the summer. There was one follow up meeting plus reporting data to EPSCoR and the camps.

Logistics. Critical logistical tasks included identifying, or-

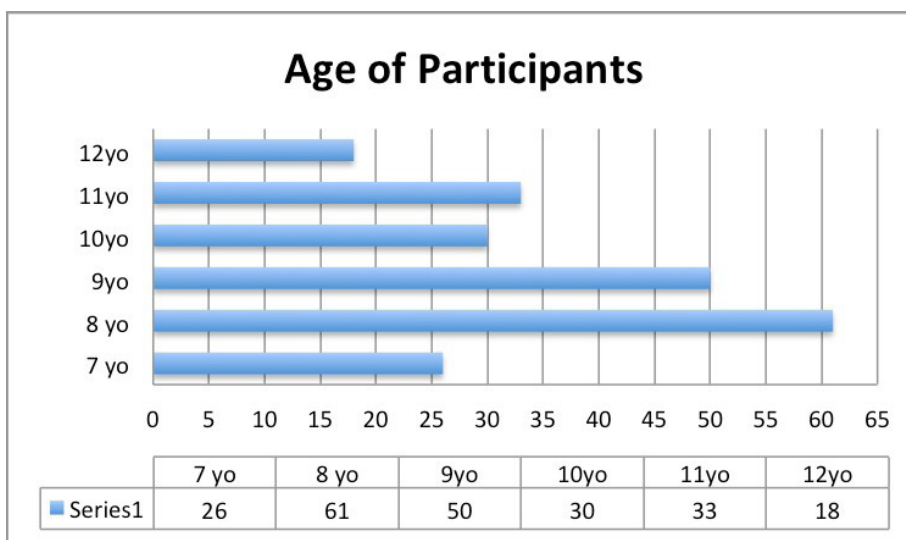

Figure 1. Age distribution of 4-H Summer of Science participants, 2017*

*Twenty-seven of the 245 completed surveys did not give age in the correct format (i.e., gave month/day of birth date instead of age or did not respond to question). Any analysis using cross-tabulation with age did not include those surveys. dering, assembling, re-stocking, disassembling, and storing the materials and supplies required to teach hundreds of youth hands-on science activities in diverse physical settings. Each intern was provided with a kit with all materials and consumable supplies needed for the entire summer. It was the interns' responsibility to stock their kit each Monday for upcoming lessons. Other logistical tasks include assembling curriculum guides for interns, preparing and submitting employee hiring forms, expense reporting, mileage submission for interns, enrollment reporting, and marketing.

The Sites. There were five day camp sites in 2016 and an additional camp from the eastern part of Maine joined the program in 2017. The five original day camp sites were within 40 miles of each other. One day camp was in an urban setting, one in a suburban setting and the other three day camps were in rural settings. The eastern Maine day camp in 2017 was in a small town setting. One site had no access to running water or electricity; all activities are designed for sites potentially lacking running water and electricity. Only one site provided a traditional classroom setting (tables, chairs, room). Other sites included an outdoor shelter, cabins, a utility room, and gym.

\section{DATA COLLECTION}

Because 2016 was a pilot year in programming at the day camp sites, the data collected were for a formative evaluation. In 2017, a pre-experimental evaluation of the 4-H Summer of Science was utilized with a post ex facto design to supplement other forms of data. The primary purpose for this design was that the day camps who hosted the six science lessons needed STEM education for all of the youth who attended their camp, eliminating any campers being a control group cohort. Also, the survey data were originally intended to collect program feedback that would inform the design and delivery of the 2018 Summer of Science. An additional consideration for eliminating a pre-program survey was the timing of the starting of the day camps: conducting a pre-survey would have meant the elimination of one of the weekly lessons, and the 2017 program had already been truncated to take the post-test survey.

Continuous data collection occurred through weekly meetings with college interns, purposeful feedback from camp staff, and observations of 4-H staff. College interns met together every Monday morning throughout the summer in an iterative evaluation process. Each week the interns and 4-H staff would identify what was working well about the program, what was not working well, what help they needed to be effective, what actions the intern needed to take to be more effective, and what the day camp sites needed to do. Interns would specifically give feedback about lesson effectiveness, student reactions to lessons, the classroom settings, 
materials and supplies, and professional development needs. At the same time, 4-H staff would share feedback received from day camps and from observations.

Demographic data and attendance were recorded at the teaching site using Google Forms on a smart phone. Interns would record gender, ethnicity, and race of participants for each session. Individual attendance was not recorded.

In the summer of 2017, a survey instrument was administered by $4-\mathrm{H}$ interns and/or 4-H staff. The survey consisted of two subscales of the 4-H Common Measures Science tool designed by National 4-H Council. The subscales were chosen (as opposed to the entire survey) based on an analysis of the 4-H Common Measures tool in California (Lewis et al., 2015). 4-H summer interns were provided training on appropriate data collection protocol including providing consistent instructions and expectations of confidentiality. An evaluation session to administer and collect the surveys from youth was scheduled in the final week of each camp after all lessons were completed. The evaluations session was planned purposefully to give time to explain the survey to youth and for the youth to complete and submit the survey. Any student who did not attend more than one session was not included in the survey results. The survey did not delineate for number of sessions attended; self-report of attendance by students was not deemed to be accurate. Parental consent was not collected because surveys were non-identifiable and data were originally planned only for program design. All parents were notified of the 4-H Summer of Science program. All youth completed a paper version of the surveys and the data were input by staff into an online database.

Survey questions were from two subscales of the National 4-H Common Measures Science survey:

- 4-H STEM participants self-reported science thinking (4 item subscale with three possible responses; Yes, Maybe, and No). This subscale was used as a pre-thenpost evaluation tool to assess self-reported agreement/ disagreement of what was learned through the 4-H STEM activities. Youth were asked specifically about what STEM thinking took place at the 4-H program.

- 4-H STEM participants self-reported agreement with statements about science or engineering (6 item subscale with 5 point Likert-type questions). This subscale was used to assess attitudes after participation in the 4-H STEM project. Youth were asked attitudes toward science and engineering. Youth were also asked what they believed could be their potential future in STEM fields. This subscale was used to observe the frequency with which "liking science" or "liking engineering" translated into the youth reporting aspirations toward studying or working in engineering or science.

Analysis. Feedback data were gathered from interns, 4-H staff, and camp staff nine times in 2016 and eight time in 2017 through weekly staff meetings and conversations with camp staff. In addition, interns provided data through an exit interview. 4-H staff reviewed minutes of weekly meetings, exit interviews, and emails to identify priority subject matter. Additional topics of concern or note were added to weekly agendas as the topics emerged during the program; a shared Google Doc allowed notes and observations to be added to agendas in real time but was rarely used by interns. Category of topics through the two summers were:

- Behavior / class management

- Lesson Plans - what worked, what didn't

- Physical teaching space

- Communications

- Administrative Issues (reporting, paperwork)

In 2017 there were 258 post-program surveys collected and entered into an online database. Analysis of the responses showed that nine respondents had skipped more than one complete page of questions and those surveys were removed from the study. Four additional surveys were removed because the respondents were not in the target age range. The result was 245 usable surveys to analyze.

Data were analyzed to assess the first research question (did the youth learn new things about science and engineering?) using a frequency distribution for the four-item self-reported science thinking subscale (see Figure 2). A frequency distribution was also used to assess if enjoyment of science or engineering translated into increased aspirations towards working or studying those subjects (see Figures 3 and 4) by using responses from the six item self-reported science attitudes subscale. Affirmative responses to the science attitudes subscale were combined (agree "a great deal" or "a lot") and negative responses were also combined (agree "a little" or "not at all").

\section{RESULTS}

Qualitative Feedback. The results of two years of evaluation (both formative and summative) include feedback response from interns, 4-H staff, and day camp staff through regular staff meetings (see Table 2) and results of the posttest survey administered to all youth after the 2017 program.

The Survey of Youth. Results from the science thinking subscale (see Figure 2) show that most youth reported that they learned new things about science after participating in the 4-H STEM activities at their day camp. Fewer youth (but still a majority) reported they learned new things about engineering. Studies have shown that the public is less informed about engineering as a term or a profession than "science" or "scientist" (National Academy of Engineering, 2002). The 2002 report by the NAE also showed that the public 
Table 2. Formative evaluation data collected in 2016 and 2017 by topic.

\begin{tabular}{|c|c|c|c|}
\hline Topic & $\begin{array}{r}\text { Source of } \\
\text { feedback }\end{array}$ & $\begin{array}{l}\text { Summer } 2016 \text { feedback } \\
\quad \text { (summarized) }\end{array}$ & $\begin{array}{l}\text { Summer } 2017 \text { feedback } \\
\text { (summarized) }\end{array}$ \\
\hline \multirow{4}{*}{ Classroom management } & \multirow{4}{*}{ Interns, 4-H staff } & A majority of youth were engaged in lessons. & Youth were generally engaged in lessons. \\
\hline & & Groups of 10-12 youth were preferable. & $\begin{array}{l}\text { The smaller group sizes in } 2017 \text { made man- } \\
\text { agement easier. }\end{array}$ \\
\hline & & $\begin{array}{l}\text { Interns needed strategies to handle difficult } \\
\text { behaviors \& unengaged students. }\end{array}$ & $\begin{array}{l}\text { Interns reported higher confidence in han- } \\
\text { dling difficult behaviors. }\end{array}$ \\
\hline & & $\begin{array}{l}\text { Camp staff often did not handle behavior prob- } \\
\text { lems (highly variable by camp site). }\end{array}$ & $\begin{array}{l}\text { Camp staff were often not handling behavior } \\
\text { problems. }\end{array}$ \\
\hline Physical teaching space & Interns, $4-\mathrm{H}$ staff & $\begin{array}{l}\text { Classrooms were often not ideal for teaching but } \\
\text { there were usually no alternatives. }\end{array}$ & $\begin{array}{l}\text { The diverse classroom spaces remained a } \\
\text { challenge. Those spaces that provided priva- } \\
\text { cy resulted in much better teaching results. }\end{array}$ \\
\hline \multirow[t]{2}{*}{ Communication } & \multirow{2}{*}{$\begin{array}{l}\text { Interns, } 4-\mathrm{H} \text { staff, } \\
\text { camp staff }\end{array}$} & $\begin{array}{l}\text { Campers were not prepared to start lessons on } \\
\text { time; they were not at the physical place at some } \\
\text { sites. }\end{array}$ & $\begin{array}{l}\text { Campers were on time for lessons more } \\
\text { frequently. }\end{array}$ \\
\hline & & $\begin{array}{l}\text { Monday morning planning and staff meetings } \\
\text { were critical to be prepared. }\end{array}$ & $\begin{array}{l}\text { Monday morning time to plan, review and } \\
\text { learn was critical. }\end{array}$ \\
\hline \multirow{5}{*}{ Lesson plans } & \multirow{5}{*}{$\begin{array}{l}\text { 4-H staff, interns, } \\
\text { camp staff, youth }\end{array}$} & $\begin{array}{l}\text { Facilitating problem-based lessons was difficult } \\
\text { for inexperienced educators. }\end{array}$ & $\begin{array}{l}\text { Interns were more confident in letting stu- } \\
\text { dents explore solutions. }\end{array}$ \\
\hline & & $\begin{array}{l}\text { The lessons had diverse, relevant and engaging } \\
\text { activities. }\end{array}$ & $\begin{array}{l}\text { Lessons were more uniform in delivery } \\
\text { method but still engaging. }\end{array}$ \\
\hline & & $\begin{array}{l}\text { Not enough time to finish all lessons; especially } \\
\text { with larger groups. }\end{array}$ & $\begin{array}{l}\text { Lessons had sections that could be skipped if } \\
\text { there was not time. }\end{array}$ \\
\hline & & $\begin{array}{l}\text { Interns provided responses about specific parts } \\
\text { of each lesson, including what materials were } \\
\text { unnecessary or were important, what steps were } \\
\text { confusing or superfluous, and what steps were } \\
\text { especially effective. }\end{array}$ & $\begin{array}{l}\text { The theme (building a structure on a Maine } \\
\text { Island) was interesting but needed to be } \\
\text { integrated more. }\end{array}$ \\
\hline & & & $\begin{array}{l}\text { Interns again provided pointed feedback on } \\
\text { specific aspects of the curriculum. }\end{array}$ \\
\hline \multirow[b]{2}{*}{ Administrative tasks } & \multirow[b]{2}{*}{ Interns } & Reporting tools were helpful. & \multirow[b]{2}{*}{ Training for time reporting was improved. } \\
\hline & & $\begin{array}{l}\text { Time reporting and mileage was time consuming } \\
\text { and confusing. }\end{array}$ & \\
\hline
\end{tabular}

had much less goodwill toward engineering than towards technology and the public weren't aware that engineering involves applications of designing.

Only about one-half of the youth participants (52.1\%) responded that they talked about science solving everyday problems in the program despite the activities being designed to do so. The activities taught in the 4-H Summer of Science were chosen to intersect with the goals of UMaine SEANET such as engineering, marine science and entrepreneurship and also be relevant to a Maine audience. When asked if they had shared their project with others less than half of students replied they had done so.

Youth reported that they liked science a great deal or a lot after participating in the 4-H Summer of Science program. However that enjoyment of science did not translate into high aspirations toward studying science or working in science (see Figure 3).
Figure 2. 4-H STEM participants self-reported science thinking.

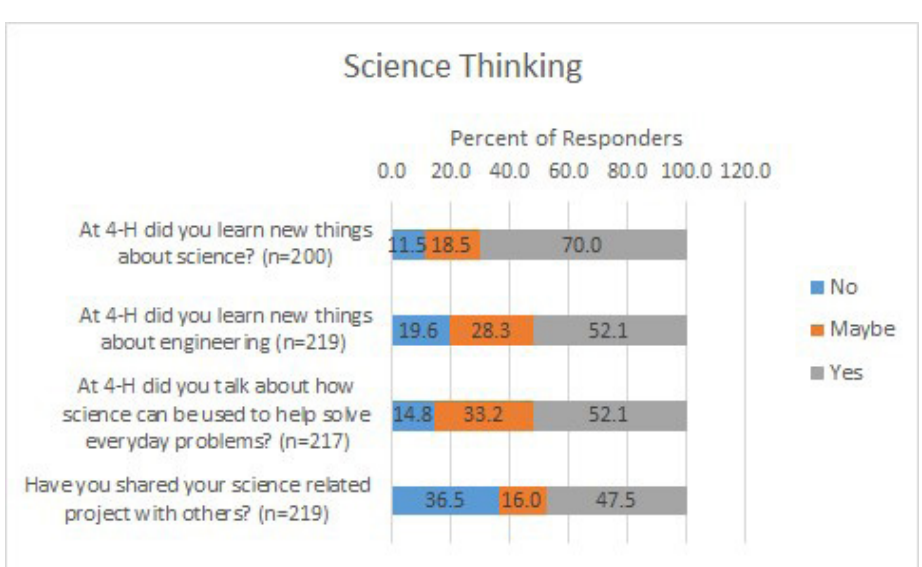


There were a much lower percentage of youth in the program that reported they liked engineering than liked science $(61.3 \%$ liked science "a great deal" or "a lot" compared to $51.3 \%$ for engineering) (see Figure 4).

Girls were slightly underrepresented in the summer STEM activities relative to the overall population $(42.1 \%$ of participants identified as female). Since no youth were actively recruited (all age-appropriate youth attending the day camp were automatically enrolled), and no youth opted into or out of the 4-H program during their day camp, there was no clear gender bias in recruitment, marketing materials or registration. The day camp partners committed in writing to adhering to all University of Maine Civil Rights policies before the program and the day camps themselves have a strong inclusion policy.

\section{DISCUSSION}

The original goal of the program was to provide effective and engaging STEM lessons to kids in the summer where they are; in this case at a summer day camp setting. This paper examines the challenges, successes, and lessons learned from delivering STEM curriculum to 3rd-6th graders in

Figure 3. 4-H STEM participants self-reported agreement with statements about science and aspirations in science.

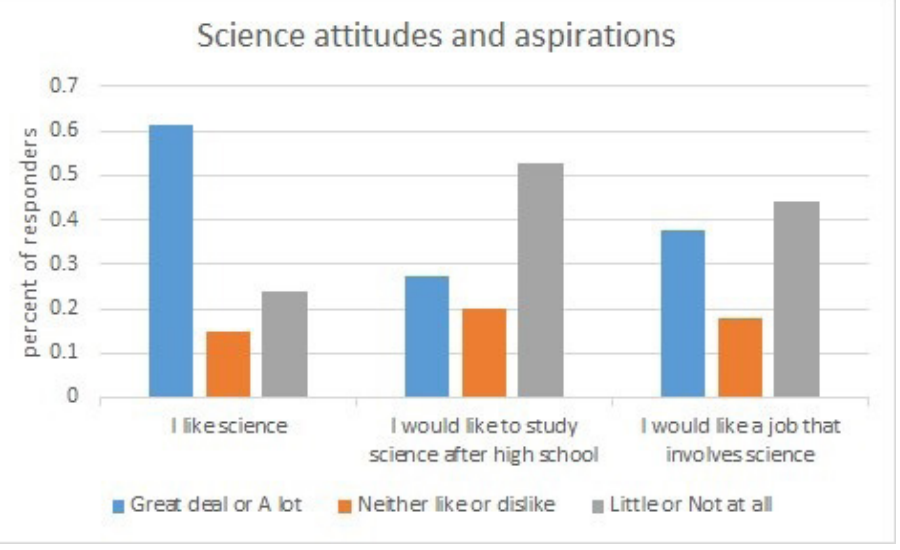

Figure 4. 4-H STEM participants self-reported agreement with statements about engineering and aspirations in engineering.

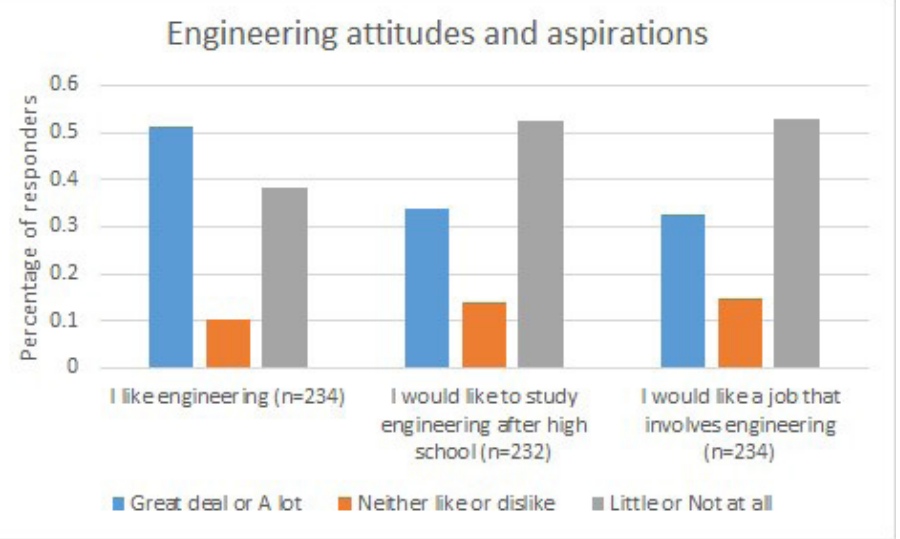

Maine during two summer day camps.

Formative evaluation collected during the iterative design process over the two summers suggests that some teaching skills, such as managing difficult behaviors, might be lacking for (relatively) inexperienced college interns. Indeed, the interns in this program expressed the need for classroom and behavior management strategies (especially during their first summer of teaching). The interns did not describe difficulties in following the lesson plan or delivering the information (with the exception of learning to apply problem-based learning techniques). All three interns were science majors (environmental science, pre-medical, and veterinary science) suggesting the content was not difficult for them to explain. Interns reported that problem-based learning required patience and time, and that they became increasingly comfortable with experience. 4-H staff and day camp staff did not report any problems with the presentation skills of the interns.

The camp settings presented unique challenges for program fidelity and consistency. The day camps hired most summer staff a few weeks prior to the STEM program starting and it takes time for staff to understand the dynamics of their young charges; the inexperience of camp staff might have been a factor in the camp staff hesitation to manage negative classroom behaviors during 4-H Summer of Science lessons. The camps are traditionally not a place where formal subjects are taught and it can be a challenge for day camp staff to transition youth from recreation to STEM learning. It was difficult for interns and 4-H staff to "go with the flow" of a malleable camp schedule. Interns learned very quickly that swimming takes priority above all else at day camps. Day camps often focus on youth social development. A university is accustomed to students coming to a central facility with the trappings of a classroom. This program is still looking at the best way to balance the informal setting (physically, temporal, structural) of a day camp with the need to deliver a lesson with specific outcomes. Increased use of place-based activities (as opposed to a uniform, canned curriculum) might be a topic for future research. More effective, and earlier, communication between 4-H staff and day camp staff would also be a variable to be explored as would additional training by and of 4-H staff.

By the second staff meeting of the 4-H Summer of Science program, interns were expected to collaboratively design agendas for successive Monday morning meetings. This strategy assured that the most important issues were raised during meetings and that interns were active problem-solvers. It became clear that interns needed assistance in handling classroom management challenges, logistics, and clear expectations of their role vs the role of program partners. The interns felt confident in the lessons and their abilities to deliver the lessons; it was usually $4-\mathrm{H}$ staff who raised methodology issues. 
Interns were expected to be problem-solvers, collaborative learners, and supportive teammates. Primary communication on program day was via text. The college age interns rarely made phone calls and often did not check their emails (4-H staff had to remind them to check emails in order to set up employment, receive payment, etc.). College interns were quick communicators. They frequently would provide instant feedback on results of lessons. It was common for an intern to deliver the first lesson of the week (usually a Monday afternoon) and then to text suggestions about that lesson to be implemented the rest of the week. It was suggested for 2018 to use an internal messaging app for group communications.

Programming at summer day camps provided an opportunity to deliver an informal STEM curriculum to several hundred youth in a safe, welcoming, and supportive setting. The physical setting (often outdoors) challenged the 4-H faculty and staff to be creative and flexible while maintaining a uniform curriculum amidst seven day camp sites.

The participants (ages 7-12) reported post program that they liked science but less so engineering. The data do not tell us why the youth responded less positively to engineering, but past research (National Academy of Engineers, 2008) suggests a lack of knowledge about the term and profession of engineering. The same past research learned that the public isn't aware of what an engineer actually does. The study found that some very important aspects of engineering such as communications, teamwork and creativity are unknown and not shared with the public.

While reviewing the written lesson plans for the 4- $H$ Summer of Science the 4-H staff realized that the words "engineer" and "engineering design process" are rarely used in the scripted portion of the lesson plans, in spite of the six lesson plans purposefully including the engineer design process into the hands-on activities. Future research might observe if there is a link between marketing engineering and participants' opinion of engineering. Future STEM programs in 4-H and with our partners should be purposeful in verbally using engineering terms (i.e., the Engineer Design Process, EDS) and then future research can assess if students still rate engineering lower than science.

It is also surprising to researchers that the youth reported liking engineering less than science because youth frequently mentioned in open-ended comments on the survey instrument that they liked the activities in which the staff used the engineer design process. When asked what they liked about 4-H Summer of Science or what they would add to the program, "Engineering" was voluntarily mentioned 13 times in the open-ended portion of the survey instrument. There were 80 responses that mentioned their favorite (and specific) engineering activity conducted during the program. Again, it is possible that youth do not recognize engineering when they experience it.
There was not a clear link between "liking science" or "liking engineering" and wanting to work with or study either subject. In fact, these data do not generate a lot of enthusiasm for a growing engineer workforce. The percent of day camp youth who reported they want to study science after high school was only $27.2 \%$ even though $61.3 \%$ of youth said they like science a great deal or a lot right now. The number of youth who said they would like to study engineering after high school was a little higher: $33.6 \%$ of students as opposed to $51.3 \%$ who said they like engineering right now a great deal or a lot.

There could be several factors playing a role in youth opinions of science and engineering. It could be that the young students don't fully understand what a scientist or engineer is or does. It could be that students wouldn't mind being a scientist or an engineer but would like some other career even more. Osborne et al., (2003) found that factors such as "(a) student motivation, (b) student self-concept, (c) peer attitudes, (d) classroom environment, (e) perception of school science, and (f) the difficulty of science", are important components of a student's choices toward science behaviors, and outweigh gender and other characteristics as an influence in selecting fields of study and work. Some studies find that for females there are other career fields that are more rewarding even when females are interested in science and engineering (Diekman et al., 2007)

Another factor could be the way youth view engineers. A 2014 Harris Interactive Poll found that only 18\% of Americans rated the engineering profession as having a great deal of prestige when compared to 22 other professions. This percentage was less than that of an athlete or an actor and was several percentage points lower than a scientist. In the same poll however, 93\% of Americans said they would recommend a child to pursue a career in engineering which made engineer the most recommended of any of the 23 professions in the poll.

There needs to be clarification about a possible disconnect between liking science and wanting a job in science. Do youth just have strong preferences for other careers? Is a STEM career intimidating? Do youth not have role models in STEM careers? This research also demonstrated that the participants did not voluntarily share what they learned in 4-H STEM with others. Is there a connection between not communicating STEM learning to not wanting a career in STEM? Is there a stigma, real or imagined, toward engineering which inhibits communication with others and also frightens students away from engineering? Perhaps adults and peers would be more supportive and encouraging about engineering as a career if they heard more about engineering in everyday life. Outreach programs should consider providing opportunities for young people to reflect and report on their learning.

\section{Staff and Partner Feedback}


General feedback about the program from the day camp staff was positive and appreciative. There was no formal evaluation process for feedback from the day camp staff. Instead, 4-H staff $(n=5)$ met weekly with camp staff, processed activities and then 4-H staff would meet faculty every Monday during the summer to assess past experiences and modify or maintain upcoming plans.

Limitations. There was not a pre-test survey conducted as part of this research project due to the original intent of the evaluation and due to the time limitations of implementing the educational programming. The absence of a pre-test survey limits conclusions to be made by participating in the Summer of Science. The youth participants were not required to attend every session in order to provide feedback through the survey (participants were required to complete more than one session however) so the directional magnitude of the effect of participation is more difficult to assess.

\section{AUTHOR INFORMATION Corresponding Author}

Mitch Mason, University of Maine Cooperative Extension 4-H, Associate Professor. mitchell.mason@maine.edu.

\section{Author Contributions}

The manuscript was written through contributions of all authors. All authors have given approval to the final version of the manuscript.

\section{FUNDING SOURCES}

2017 Summer of Science activities were based on the theme Innovation Engineering, with support and materials provided by Maine EPSCoR, Maine 4-H Foundation, USDA/NIFA Children Youth and Families at Risk Grant, and Walmart Foundation.

\section{ABBREVIATIONS}

EPSCoR: Established Program to Stimulate Competitive Research; MEA: Maine Educational Assessment; SEANET: Sustainable Ecological Aquaculture Network; SFSP: Summer Food Service Programs; STEM: Science, Technology, Engineering, and Math
Arnold, M.E., Bourdeau, V.D., and Nott, B.D. (2013). Measuring science inquiry skills in youth development programs: the science process skills inventory. Journal of Youth Development, 8(1) Article 130801FA001. Retrieved from http:// jyd.pitt.edu/ojs/jyd/article/view/103/89

Bassano, L., and McConnon, J., Jr. (2011). Strategic partnerships that strengthen Extension's community-based entrepreneurship programs: An example from Maine. Journal of Extension, 49(5) Article 5FEA3. Retrieved from https:// joe.org/joe/2011 october/a3.php

Braund, M., and Michael Reiss, M. (2007) Towards a more authentic science curriculum: The contribution of out-of-school learning., International Journal of Science Education, 28(:12), 1373-1388, doi: 10.1080/09500690500498419

Bybee, R. 2015. The BSCS 5E instructional model: Creating teachable moments. Arlington, Virginia: NSTA Press.

Diekman, A.B., Steinberg, M., Brown, E.R., Belanger, A.L., and Clark, E.K. (2017). A goal congruity model of role entry, engagement, and exit: understanding communal gap processes in STEM gender gaps. Personality and Social Psychology Review. 21(2), 142-175, doi: $10.1177 / 1088868316642141$

Dillivan, K.D., and Dillivan, M.N. (2014). Student interest in STEM disciplines: results from a summer day camp. Journal of Extension. 52(1) Article 1RIB5. Retrieved from https://joe.org/joe/2014february/rb5.php

Gibson, H. L., and Chase, C. (2002). Longitudinal impact of an inquiry-based science program on middle school students' attitudes toward science. Science Education, 86, 693-705.

Harris Interactive Poll (2014), Prestige of 23 professions and occupations, Harris Poll \#85 [date file]. Retrieved from https:// theharrispoll.com/when-shown-a-list-of-occupations-andasked-how-much-prestige-each-job-possesses-doctorstop-the-harris-polls-list-with-88-of-us-adults-considering-it-to-have-either-a-great-deal-of-prestige-45-2/.

Haugen, H., Stevenson, A., and Meyer, R. (2014). Participant comfort with an application of inquiry-based learning: results from a 4-H volunteer training. Journal of Extension. 54(1 Article 1FEA5. Retrieved from https://www.joe.org/ joe/2016february/a5.php.

Judson, E. (2013). The relationship between time allocated for science in elementary schools and state accountability policies. Science Education, 97(4). Retreived from: https:// onlinelibrary-wiley-com.prxy4.ursus.maine.edu/doi/ epdf $/ 10.1002 /$ sce. 21058

LaForce, M., Noble, E., and Blackwell, C. (2017). Problem-based learning (PBL) and student interest in STEM careers: the roles of motivation and ability beliefs. Education Sciences, 7(4), 92. Retrieved from: https://doi.org/10.3390/educsci7040092.

Lewis, K.M., Horrillo, S.J., Widaman, K., Worker, S.M., and Trzesniewski, K. (2015). National 4-H Common Measures: initial evaluation from California 4-H. Journal of Extension. 53(2) Article 2RIB3. Retrieved from https://joe.org/ joe/2015april/rb3.php.

\section{REFERENCES}

Lou, SJ., Shih, RC., Ray Diez, C., and Tseng KH., (2010). The 
impact of problem-based learning strategies on STEM knowledge integration and attitudes: an exploratory study among female Taiwanese high school students. International Journal of Technology and Design Education, 21(2). Retrieved from: https://doi-org.prxy4.ursus.maine. edu/10.1007/s10798-010-9114-8

Maine Department of Education. (2017). Maine educational assessment for science. Retrieved from http://www.maine. gov/doe/mea/index.html

Maine Science Teachers Association. (2017). Science standards survey. Unpublished raw data.

Miller, E., Baxter Lauffer, H., and Messina, P. (2014). NGSS for English language learners: from theory to planning to practice. Science and Children, 51(5), 10-13.

Moss-Racusin, C.A., Sanzari, C., Caluori, N., and Rabasco, H., (2018). Gender bias produces gender gaps in STEM engagement. Sex Roles. Retrieved from https://doi-org. prxy4.ursus.maine.edu/10.1007/s11199-018-0902-z.

National Academy of Engineering. (2002). Raising public awareness of engineering. Retrieved from: https://doi. org/10.17226/10573

National Academy of Engineering. (2008). Changing the conversation: Messages for improving public understanding of engineering. Washington, D.C: National Academies Press.

National 4-H Council. (2012). National 4-H logic model. Retrieved from https://4-h.org/professionals/common-measures/national-4-h-logic-model/

National Research Council. (2012). A framework for K-12 science education: practices, crosscutting concepts, and core ideas. Committee on a Conceptual Framework for New K-12 Science Education Standards. Board on Science Education, Division of Behavioral and Social Sciences and Education. Washington, DC: The National Academies Press.

National Research Council. (2009). Learning science in informal environments: people, places, and pursuits. Retrieved from: https://www.nap.edu/catalog/12190/learning-science-in-informal-environments-people-places-and-pursuits.

National Science Foundation. (2018). OIA's established program to stimulate competitive research (EPSCoR) section Retrieved from https://www.nsf.gov/od/oia/programs/epscor/

Nelson, G.D., and Landell, C.C. (2007). A collaborative approach for elementary science. Educational Leadership, 64(4), 7275.

Ripberger, C., and Blalock, L. B. (2011). 4-H science in urban communities promising practices guide. Retrieved from http://urban4hscience.rutgers.edu

Romich, E., and Campbell, J. (2015). Partnering with private industry - ground rules for working together. Journal of Extension, 53(4) Article 4IAW2. Retrieved from https://joe. org/joe/2015august/iw2.php

Safford, T.G., and Hamilton, L.C. (2012). Demographic change and shifting views about marine resources and the coastal environment in Downeast Maine. Population and Environment, 33:284. https://doi-org.prxy4.ursus.maine. $\mathrm{edu} / 10.1007 / \mathrm{s} 11111-011-0146-0$.
Scutchfield, F.D., Harris, T.T., Tanner, B., and Murray, D. (2007). Academic health centers and Cooperative Extension Service: a model for a working partnership. Journal of Extension, 45(1) Article 1FEA5. Retrieved from https://www. joe.org/joe/2007february/a5.php.

Seevers, B., and Stair, K. (2015). Exploring community partnerships in agricultural and extension education. Journal of Extension, 53(3) Article 3RIB1. Retrieved from https:// www.joe.org/joe/2015june/pdf/JOE_v53_3rb1.pdf.

Shanahan, M.C., Pedretti, E., DeCoito, I., and Baker, L. (2011). Exploring the responses of underrepresented students in science to an elementary classroom outreach program. School Science \& Mathematics, 111(4), 131-142.

Silvernail, D.L., and Mazjanis, B. (2015). Report to the joint standing committee on education and cultural affairs Maine state legislature. Maine Education Policy Research Institute. Retrieved from http://digitalcommons.usm.maine. edu/cepare_improvement/4/.

Stake, J.E. (2006). The critical mediating role of social encouragement for science motivation and confidence among high school girls and boys. Journal of Applied Social Psychology, 36, 1017-1045.

U.S. Census Bureau. 2018. QuickFacts Maine. Retrieved from https://www.census.gov/quickfacts/fact/table/ME/ PST045217

U.S. Department of Agriculture, National Institute of Food and Agriculture. 2018. Cooperative extension system. Retrieved from https://nifa.usda.gov/cooperative-extension-system.

Wallace, R.D., Bouvier, R., Yeitz, L.M., and Colgan, C.S. (2017). The economic contribution of Casco Bay. Maine Center for Business and Economic Research. Retrieved from https:// www.cascobayestuary.org/wp-content/uploads/2017/11/ CBEP-Economic-Study-Final-Report-11.21.17.pdf. 